161.

\title{
0.3T MRI装置における3D-SSFP計測 3D-SSFP Acquisitions with 0.3T MRI
}

\author{
(株) 日立メディコ 技術哊究䜣 \\ （株）日立製作泝 小火研谷折
}

○僟部正惉 渡部泓
(Masayuki Isobe) (Shigeru Watanabe) (Hiroshi Nishimura)
谷口陽 川本悦治
(You Taniguchi) (Etsuji Yamamoto)

[目的]

3D撮像においては短TRの䚵測が岁求されるが、短TRでT2(T2*)強調像を得る手段としてSSFP計測法がある。 今回3種類のSSFP系列パルスシーケンスを開発し、䫒部に挍けるコントラストの比較を行った。

[方法]

使用装置は日立MRP-7000(0.3T永人磁不门式)である。作成したSSFP系列パルスシーケンスは、(1)位相および スライスエンコード傾斜磁場のrewindを行い、FIDとSSFPエコーを重ね合わせて刻測するSARGE(Steady state Ac-

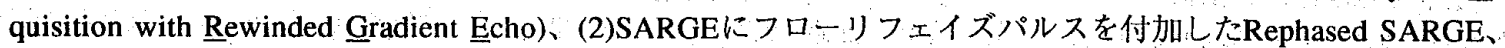
(3)SARGEに対して傾斜磁場印打順序を特䦌似に逆転させ、SSFPエコーのみを䚵測するTime-reversed SARGEの 3種類である。この3種類の3D-SSFP系列パルスシーケンスについて、健常者顕部を対象としてコントラストの比 較を行った。

[結果]

図1に(a)SARGE,(b)Time-reversed SARGEのフリップ角の違いによる脳組織の信号強度変化を示す。

SARGEは、SSFPエコーとFIDを闰恃に换測するため、FIDのみを計测する非SSFPシーケンスに比へS/Nが向上 しており、T1,T2の雨者が反映されたコントラストを早する。低フリップ角ではFIDの影響によりT1強調となり、 高フリップ角ではSSFPエコーが文配似になり、T2の長い組織が強調される。

Rephased SARGEは、フローリフェイズ効果により、CSFの信号強度が增し、SARGEより強度のT2強調像が得 られた。また、TOF-Angiographyに伈刚した場会、此較的T2の長い血液の作号強度の上昇効果で、末梢血管の描 出能が改善できる。

Time-reversed SARGEは、SSFPエコーのみを棓測するため、短TRでも強いT2(T2*)コントラストが得られた。 図2にTime-reversed SARGEにより撮像した脳表西像を示す。

[結論]

3D計測におけるT2(T2*)強調西傢取得を目的として、3種類のSSFPパルスシーケンスを作成し、下記の結論を 得た。

1.SARGEおよびRephased SARGEは、非SSFP垶測に比べ高フリップ角でT2強調效果が得られた。また、

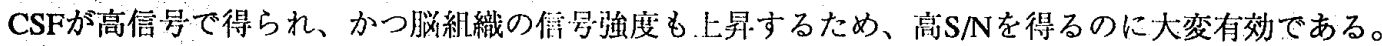

2. Time-reversed SARGEは強度のT2(T2*)強調画像の取得が可能であり、脳表画像や低速流を対象とした Angiographyへの適用も期街できる。

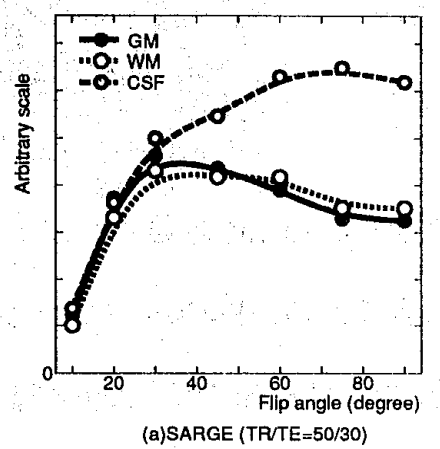

図1: フリップ角の違いによる信多強度変化

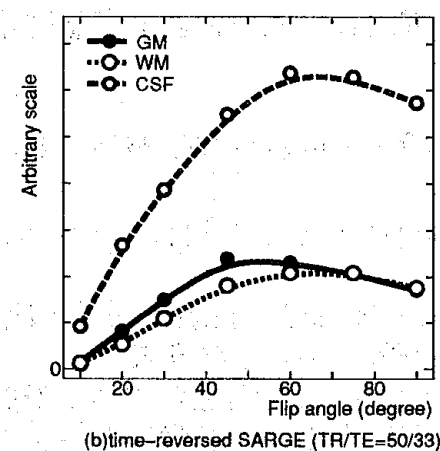

(b) time-reversed SARGE (TA/TE $=50 / 33$ ) 肬表画像(MIP処理)

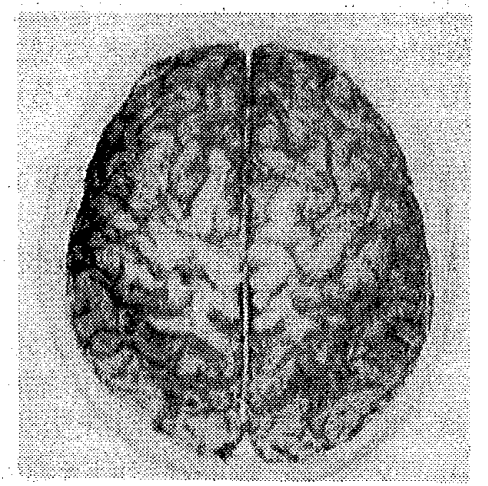

図2: time-reversed SARGEによる 